\section{Glucagon-like peptide 1}

R. Tauber und F. H. Perschel

Institut für Laboratoriumsmedizin, Klinische Chemie und Pathobiochemie, Charité - Universitätsmedizin Berlin, Campus Virchow-Klinikum, Berlin, Deutschland

Synonym(e) Glukagon-ähnliches Peptid

Englischer Begriff Glucagon-like peptide 1

Definition Glucagon-like peptide 1 (GLP 1) ist ein intestinales Peptidhormon, das mit Glucagon-like peptide 2 und Glukagon aus einer gemeinsamen Vorstufe (Proglukagon) gebildet wird.

Beschreibung GLP 1 entsteht aus Prä-Proglukagon, das im ZNS, den L-Zellen des Dünndarms und im Pankreas gebildet wird. Im Pankreas wird $\triangleright$ Glukagon freigesetzt, während der
Anteil, der GLP 1 und GLP 2 enthält, als großes, inaktives Peptid sezerniert wird. Im Darm und im ZNS hingegen verbleibt die Glukagonsequenz in einem größeren Peptid (Glicentin), während GLP 1 und GLP 2 freigesetzt und sezerniert werden. Die Freisetzung von GLP 1 aus dem Dünndarm erfolgt 5-30 Minuten nach Nahrungsaufnahme entsprechend der zugeführten Kalorienmenge. Steigende GLP 1-Konzentration im Plasma führt zu postprandialem Sättigungsgefühl sowie zu einer Hemmung der Magensäuresekretion und -motilität. Es gibt Hinweise darauf, dass verminderte GLP 1-Sekretion zu der Entstehung von Übergewicht beiträgt und GLP 1 für einen therapeutischen Ansatz geeignet ist.

\section{Literatur}

Stanley S, Wynne K, Bloom S (2004) Gastrointestinal satiety signals. III. Glucagon-like peptide 1, oxyntomodulin, peptide YY and pancreatic polypeptide. Am J Physiol Gastrointest Liver Physiol 286: G693-G697 